\title{
Analysis of Tree Species Preference and Reasons among Commercial Charcoal Producers in Nasarawa State, Nigeria
}

\author{
Ekpo Abraham Salamatu, Haruna Kuje Ayuba, Danjuma N. Marcus, and Adamu Tanko Ogah
}

\section{ABSTRACT}

Commercial charcoal production has over time become an indispensable means of livelihood among rural settlers in Nasarawa State. However, charcoal production involves woodland exploitation which contributes to deforestation. Considering the growing significance of charcoal in rural and urban livelihoods in Nasarawa State, this paper analysed the preference of tree species and reasons among commercial charcoal producers in Nasarawa State in view of identifying endangered species and suggesting measures to ensure sustainability of the business. The study employed descriptive survey using both qualitative and quantitative data drawn from primary and secondary sources. Questionnaire was administered to 450 respondents randomly sampled from commercial charcoal producers drawn from 6 communities and 3 LGAs of Nasarawa State. Interviews and Focus Group Discussions were also conducted and the data obtained were analysed using descriptive and inferential statistics in Microsoft Excel and SPSS (version 23). A total of 22 tree species were identified as usable for charcoal production in the study area. Investigation into the producers' preference of tree species showed that eight $(8)$ were mostly preferred out of which Anogeissus leiocarpus (Marke) (57.3\%), Erythrina senegalensis (Madri) (52.2\%) and Prosopis Africana (Kirya) (49.1\%) were among the top three. Marke, Kirya and Madri were the most preferred species in Akwanga, Doma and Karu production areas respectively. High charcoal yield, good combustion quality, high heat content of resulting charcoal, less ash production were the main reasons for their preferences. Most of the preferred tree species have been depleted to the point that they are no longer commonly found for use among commercial charcoal producers in the state. The most endangered species due to commercial charcoal production were Anogeissus leiocarpus (Marke), Erythrina senegalensis (Madri) and Prosopis Africana (Kirya). However, pressure is currently on Teminalia glocosece (Baushe/Uko), Andira inermis (Gwaska), Ficus Spp (Baure), Vitellaria paradoxa (Kede) and Gardinia aqualla (Gaude) due to the difficulties in finding the endangered ones which constituted the most preferred species among producers in Nasarawa State. It was recommended that state energy policies should incorporate a law recognizing charcoal as a key source of energy in the State, thereby encouraging investments in the activity of commercial charcoal producers. Furthermore, conservation plans and practical measures of replacing the extracted trees from woodlands/forests for commercial charcoal production should form the basis for license issuance for charcoal production.

Keywords: Charcoal, Commercial, Tree-species and Woodland.
Published Online: April 02, 2021

ISSN: $2684-446 \mathrm{X}$

DOI :10.24018/ejgeo.2021.2.2124

Ekpo Abraham Salamatu *

Department of Environmental Management, Faculty of Environmental Science, Nasarawa State University, Nigeria.

(e-mail: abrahamsalamatu@ gmail.com) Haruna Kuje Ayuba

Department of Environmental Management, Faculty of Environmental Science, Nasarawa State University, Nigeria.

(e-mail: hkayuba@yahoo.com)

Danjuma N. Marcus

Department of Geography, Faculty of Environmental Science, Nasarawa State University, Nigeria.

(e-mail: marcusdanjuma@ ${ }^{\circledR}$ ahoo.com) Adamu Tanko Ogah

Department of Geography, Faculty of Environmental Science, Nasarawa State University, Nigeria.

*Corresponding Author

\section{INTRODUCTION}

Forest and woodlands provide a broad range of products, services and functions to the human race such as timber for construction, fuelwood. In most developing regions of Africa, they contribute immensely to economic, social and ecological (erosion prevention, conservation of table water and soil vitality) wellbeing the of the environment. The impact of wood fuel and its derivative (charcoal) gotten from forested woodlands, on the energy requirements of developing nations cannot be ignored. It supplies about 95 percent of the cooking energy needs in the developing countries [1]. In spite of the benefits derived from the forest and forest products, the world's forest is rapidly depleting due to the rate of dependence on the savannah woodlands, and it has exposed it to degradation, these have attracted concerned sectors of the world government in finding ways to curtail this increasing menace against nature.

Nigeria once ranked second to Brazil in the production and export of charcoal. The western countries particularly prefer Nigeria's charcoal, as it is rich in tropical hardwood, which burns slower and heats faster. Nigeria now exports an 
estimated 380,000 metric tonnes of charcoal annually [2]. In 2010, Nigeria had 8.9Mha of forest cover, extending over $9.8 \%$ of its land area. It provides refuge for everything from rare and endangered plants and animals to ferocious militias accused of brutal crimes against humanity. In 2016, it lost $72 \mathrm{kha}$ of forest, equivalent to $5.4 \mathrm{Mt}$ of $\mathrm{CO}_{2}$ of emissions [3]. It is difficult to imagine that such vast ancient woodlands are at risk of extinction. But they are disappearing at an alarming rate. According to the UN Food and Agriculture Organization cited in [4], indigenous (also known as "old-growth") forests in Africa are being cut down at a rate of more than 4 million hectares per year which is twice the world's deforestation average. According to the FAO, losses totalled more than 10 percent of the continent's total forest cover between 1980 and 1995 alone. Furthermore, the Government of Nigeria [5] estimates that, about 150 trucks transport charcoal to markets within and beyond North Central region per week. Households produce about 25 maxi bags of charcoal per month and sell about 95 percent of the output either within or outside the region. This poses a worrying threat to the natural existence of tree biodiversity in the study area and the assertion (i.e., threatened forest) is underpinned by the Resource Watch Agenda's claim that extractions from the forest outpace the rate of forest replacement [6]. With Nigeria losing about 3.5 percent of its forest yearly, which is between 350,000 and 400,000 [7], hectares of forestland, the World Bank has extended Nigeria Reducing Emissions from Deforestation and Forest Degradation (REDD+) Readiness Programme to Nasarawa.

Charcoal production involves woodland exploitation which contributes to deforestation. Martin et al, [4] noted that deforestation is associated with various negative consequences: the loss of valuable resources and dangerous interference with the environment. Today, for instance, it is being recognised that deforestation drives climate change through the release of large amounts of greenhouse gases that fuel global warming; it reduces the bio-productivity of ecosystems by disrupting the habitats of thousands of species, and often transforms forest lands into barren deserts. It also exposes bare surfaces which are susceptible to soil erosion, thus making the entire ecosystem unstable. Consequently, by impoverishing our natural environments, in the long run deforestation affects our lives and economy negatively. Over the years, sustainable management of forest resources has been of primary concern due to its potential impact on biological diversity and importance in maintaining global ecological functions.

The United Nations Sustainable Development Goal (SDG) number 15 was set to protect, restore and promote sustainable use of terrestrial ecosystems, sustainably manage forests, combat desertification, and halt and reverse land degradation and halt biodiversity loss. Also, its Global Forest Goal 1 seeks to reverse the loss of forest cover worldwide through sustainable forest management, including protection, restoration, afforestation and reforestation, and increase efforts to prevent forest degradation and contribute to the global effort of addressing climate change. The various sections of the goals addresses different aspects towards the management of global forest as follows: section 1.1 seeks to increase global forest area by $3 \%$; section 1.2 seeks to ensure that the worlds forest carbon stocks are maintained or enhanced; section 1.3 seeks to promote the implementation of sustainable management of all types of forest, halt deforestation, restore degraded forest and sustainably increase afforestation and reforestation globally; while section 1.4 is targeted towards strengthening the resilience and adaptive capacity of all types of forest to natural disasters and the impacts of climate change. United Nations Forum on Forest (UNFF) [8], addresses issues of biodiversity degradation, sustainable production and women empowerment as outlined in goals numbers 5 (Achieve gender equality and empower all women and girls), 12 (Ensure sustainable consumption and production patterns), 13 (Take urgent action to combat climate change and its impacts) and 15 (Protect, restore and promote sustainable use of terrestrial ecosystems, sustainably manage forests, combat desertification, and halt and reverse land degradation and halt biodiversity loss).

In order to understand the nexus between charcoal production and woodland exploitation and devise sustainable approaches to the business, it is imperative to first understand producers' preferences of tree species and their reasons. Even though all species of wood can be carbonized to charcoal, the quality of charcoal varies from specie to specie and is dependent on the method of carbonization [9]. Large tree species (>20 cm diameter) with high caloric values are the most preferred, due to the large quantity of dense and hard charcoal they produce [10]. Charcoal can be made from both hard wood and soft woo species. The wood species for charcoal are classified into soft and hard based on the period it takes to be converted into ashes. However, hard wood species are usually preferred because charcoal from such species has higher energy content, burns slowly over longer periods and often leaves less ash residue and dust [11]. The targeting of particular tree species for the production of charcoal has made charcoal production and use a major driver of forest cover depletion. Local tree species are the target for majority of the charcoal produced in Sub-Saharan Africa, including Nigeria. Therefore, this paper assesses commercial charcoal producers' preferences of tree species and their reasons.

\section{MATERIALS AND METHODS}

The study was carried out in Nasarawa state. The state has an approximate land area of about $27,271.50 \mathrm{~km}^{2}$ and located in the basement complex of north-central Nigeria between longitude $6^{\circ} 45^{\prime} 03$ ' and $9^{\circ} 45^{\prime} 03$ ' of the Greenwich meridian and latitude $7^{\circ} 45^{\prime} 00^{\prime}$ ' and $9^{\circ} 35^{\prime} 00^{\prime}$ ' of the equator. It stands at an elevation of 400 meters above sea level. It shares geographical boundaries with Kaduna state in the north, Federal Capital Territory (FCT) in the west, Kogi and Benue states in the south, Taraba and Plateau states in the east. Nasarawa State has a population of 1,926,221 as the current projected population with a population density of $75 / \mathrm{km}^{2}(190 / \mathrm{sg} \mathrm{mi})$ making it one of the most densely populated States in the country [12]. The vegetation of Nasarawa state is Guinea savanna and the floristic composition is heterogeneous with a variety of species made up of small trees (scattered), interspersed with shrubs, grasses and arable crops. Parkia biglobosa is the dominant tree species found in the area. 


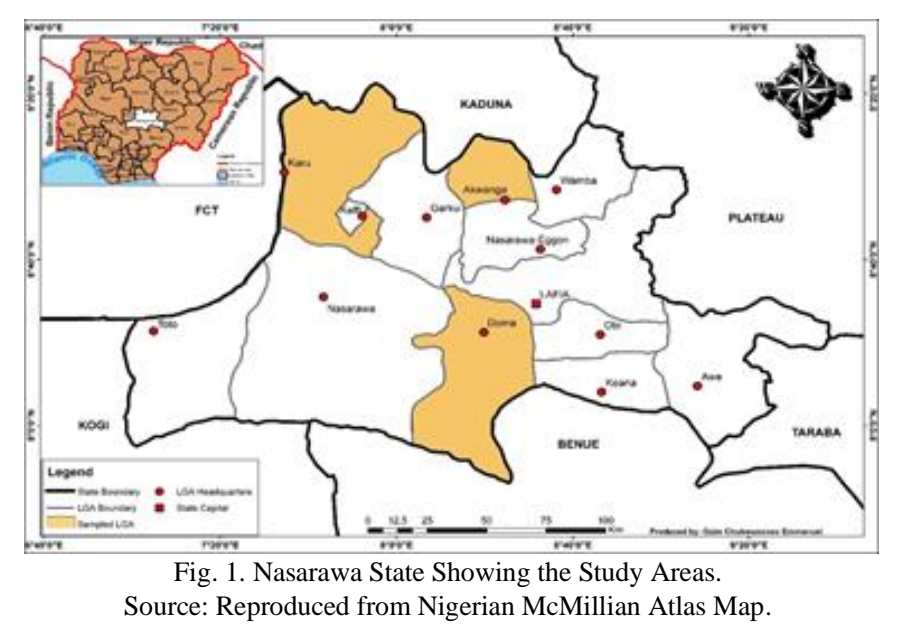

Based on the number of producers identified to be involved in commercial charcoal production in each of the selected six study communities, the Krejcie and Morgan's sample size determination table [13] was used to select appropriate samples for the study. The number of producers identified in each community and its associated sample size are presented in Table I.

\begin{tabular}{cccc}
\multicolumn{4}{c}{ TABLE I: SAMPLE Size DETERMINATION } \\
\hline \multirow{2}{*}{ LGA } & Community & Population & $\begin{array}{c}\text { Sample } \\
\text { Size }\end{array}$ \\
\hline Akwanga & Aricha & 85 & 70 \\
& Gudi & 85 & 70 \\
Doma & Agwashi & 55 & 48 \\
& Idadu & 90 & 73 \\
Karu & Songo-Gitata & 120 & 92 \\
& Saningye-Panda & 130 & 97 \\
Total & & & 450 \\
\hline Source: Reconnaissance Survey/Krejcie and Morgan (1970).
\end{tabular}

This paper utilized both qualitative and quantitative data. The data collected were in line with the aim of the paper. The study drew from both primary and secondary sources of data. Primary data on socioeconomic status of the people involved in commercial charcoal production; the reasons why they engage in charcoal production; the preferred tree species for the production and reasons, were sourced for the study. Secondary data were obtained from publications, annual and quarterly reports and books (hard and soft copies) that deals with the concepts and issues of charcoal production and tree biodiversity. Preparatory to data collection, reconnaissance survey was carried out in the study area prior to the administration of questionnaire, conducting of interviews and focus group discussion. This enabled familiarization with, as well as obtaining of first-hand information about the study area through observation and casual interactions with the people. During this process, the village heads of the study communities were identified, and meetings were held with them to explain the purpose (academic research) of our visit to their communities and to explain what we would be doing in the course of data collection so as to obtain official permission from them.

Questionnaire containing both open and closed-ended questions was used as a tool for data collection. It was administered to commercial charcoal producers in the study area and to ensure thoroughness, respondents were enlightened on how to answer the questionnaire, and were also assisted in the case of personal disability or language barrier. A total 450 copies of the questionnaire were administered to the sampled respondents. In addition, interviews and Focus Group Discussion (FGD) were conducted to enhance the data collected through questionnaire. The focused group discussion was conducted amongst three groups of producers based on age categories with gender balance comprising of 8-12 participants in each group having younger generation producers (30 years and below), middle age producers (31-45 years) and older generation producers (46 years and above). Two FGD sessions per age group were conducted in each of the selected communities in the study Area.

The acquired data was analysed using descriptive (tools: frequencies, means, percentages and cross-tabulation) and inferential (tools: chi-square) statistics. The raw data collected from the field was coded and analysed using Microsoft Excel spreadsheet (office 2016) and SPSS version 34. The results of the analysis were presented in form of tables and charts. Data which was obtained from key informants and focus group discussions were stored in audio recordings which were analysed based on the techniques outlined by Milles and Huberman [14] which stated that qualitative data analysis should consist of three stages, data reduction, data display, and conclusion drawing.

\section{RESUlTS AND DisCUSSION}

\section{A. Tree Species Used for Commercial Charcoal Production in Nasarawa State}

The various tree species used for commercial charcoal production in the study area as identified by the respondents are presented in Table II.

A total of 22 species of tree were discovered to be utilized for commercial charcoal production in the study area out of which; Prosopis Africana (Baushe/uko), Ficus Spp (Baure), Erythrina senegalensis (Gwaska), Vitellaria paradoxa (Kede) and Anogeissus leiocarpus (Gaude), were found to be among the most commonly used as indicated by $95.8 \%$, $85.8 \%, 85.3 \%, 75.3 \%$ and $53.8 \%$ of the sampled respondents respectively. Vitex doniana (Dinya), Gardinia aqualla (Marke), Sereyaba, Teminalia glocosece (Kirya), Pasaga, Afzelia Africana (Kaawoo), Daniela Oliveri (Maje/Kaduara) and Andira inermis (Madri) were also identified as popular tree species for commercial charcoal production in the study area by $33.3 \%, 28.7 \%, 24 \%, 24 \%, 22.7 \%, 21.8 \%, 20.9 \%$ and $16.9 \%$ of the sampled charcoal producers. Furthermore, $14.7 \%$ of the respondents listed Borassus aethiopum (Giginya) as one of the tree species they use for charcoal production, $14.2 \%$ listed Umbeso and $13.3 \%$ listed Pericopsis laxiflora (Markafo). Khaya senegalensis (Madachi) and Burkia Africana (Kolo) were listed by $10 \%$ and $9.3 \%$ respectively.

Although Isober linadoka (Dooka), Piliostigrna thoniugii (Kargo), Parkia biglobossa (Dorowa) and Pterocarpus erinaceus (Madobiya/Shajini) were also listed among the tree species that can be used for charcoal production, they were unpopular among commercial charcoal producers in the study area as only $7.8 \%, 7.8 \%, 7.8 \%$ and $6.4 \%$ of the respondents claimed to use or have used them for charcoal production. The most commonly used species for charcoal production in 
the area did not correspond with the most preferred species. This could be due to the difficulties in obtaining the preferred species most of which the producers claimed to have been massively depleted, hence difficult to find.

TABLE II: TREe SPECIES USED FOR COMMERCIAL CHARCOAL PRODUCTION (MUlTiPle ResPONSE)

\begin{tabular}{|c|c|c|c|c|c|c|}
\hline & $\begin{array}{c}\text { Tree } \\
\text { Species }\end{array}$ & & Akwanga & Doma & Karu & Total \\
\hline $\begin{array}{c}\text { Local Name } \\
\text { (Hausa) }\end{array}$ & Botanical Name & English Name & Freq $(\%)$ & Freq $(\%)$ & Freq $(\%)$ & Freq $(\%)$ \\
\hline Baushe/Uko & Teminalia glocosece & & $137(97.8)$ & $115(95.0)$ & $179(94.7)$ & $431(95.8)$ \\
\hline Gwaska & Andira inermis & Cabbage back & $121(86.4)$ & $109(90.1)$ & $154(81.5)$ & $384(85.3)$ \\
\hline Baure & Ficus Spp & Ficus/fig tree & $97(69.3)$ & $100(82.6)$ & $189(100)$ & $386(85.8)$ \\
\hline Kede & Vitellaria paradoxa & Shea tree & $112(80.0)$ & $90(74.4)$ & $137(72.5)$ & $339(75.3)$ \\
\hline Gaude & Gardinia aqualla & Gueded coffee & $118(84.3)$ & $74(61.2)$ & $50(26.5)$ & $242(53.8)$ \\
\hline Dinya & Vitex doniana & Black plum & $44(31.4)$ & $38(31.4)$ & $68(36.0)$ & $150(33.3)$ \\
\hline Sereyaba & & & - & $108(89.3)$ & - & $108(24.0)$ \\
\hline Marke & Anogeissus leiocarpus & & $40(28.6)$ & $29(24.0)$ & $60(31.7)$ & $129(28.7)$ \\
\hline Kaawoo & Afzelia Africana & Bambara & & $98(81.0)$ & - & $98(21.8)$ \\
\hline Pasaga & & & $102(72.9)$ & - & - & $102(22.7)$ \\
\hline Kirya & Prosopis africana & Iron tree & $42(30.0)$ & - & $66(34.9)$ & $108(24.0)$ \\
\hline Madri & Erythrina senegalensis & Flame tree & - & $76(62.8)$ & - & $76(16.9)$ \\
\hline Maje/Kadaura & Daniela Oliveri & Copal tree & $17(12.1)$ & $11(9.1)$ & $66(34.9)$ & $94(20.9)$ \\
\hline Umbeso** & & & $64(45.7)$ & - & - & $64(14.2)$ \\
\hline Markafo & Pericopsis laxiflora & Baker & $17(12.1)$ & $19(15.7)$ & $24(12.7)$ & $60(13.3)$ \\
\hline Giginya & Borassus aethiopum & Fan palm & $-/-$ & - & $66(34.9)$ & $66(14.7)$ \\
\hline Madachi & Khaya senegalensis & Mahogany & $24(17.1)$ & $21(17.4)$ & - & $45(10.0)$ \\
\hline Kolo & Burkia africana & Wild Springa & $11(7.9)$ & $31(25.6)$ & - & $42(9.3)$ \\
\hline Dooka & Isober linadoka & & $7(5.0)$ & $12(9.9)$ & $16(8.5)$ & $35(7.8)$ \\
\hline Kargo & Piliostigrna thoniugii & & - & - & $35(18.5)$ & $35(7.8)$ \\
\hline Dorowa & Parkia biglobossa & Locust bean & - & - & $35(18.5)$ & $35(7.8)$ \\
\hline Madobiya/Shajini & Pterocarpus erinaceus & Moninga & - & - & $29(15.3)$ & $29(6.4)$ \\
\hline
\end{tabular}

Note: (-) means not mentioned in the Local Government; (**) Means name is not in Hausa (it's in Lindere dialect) and Freq = Frequency.

Source: Field Data Analysis 2018.

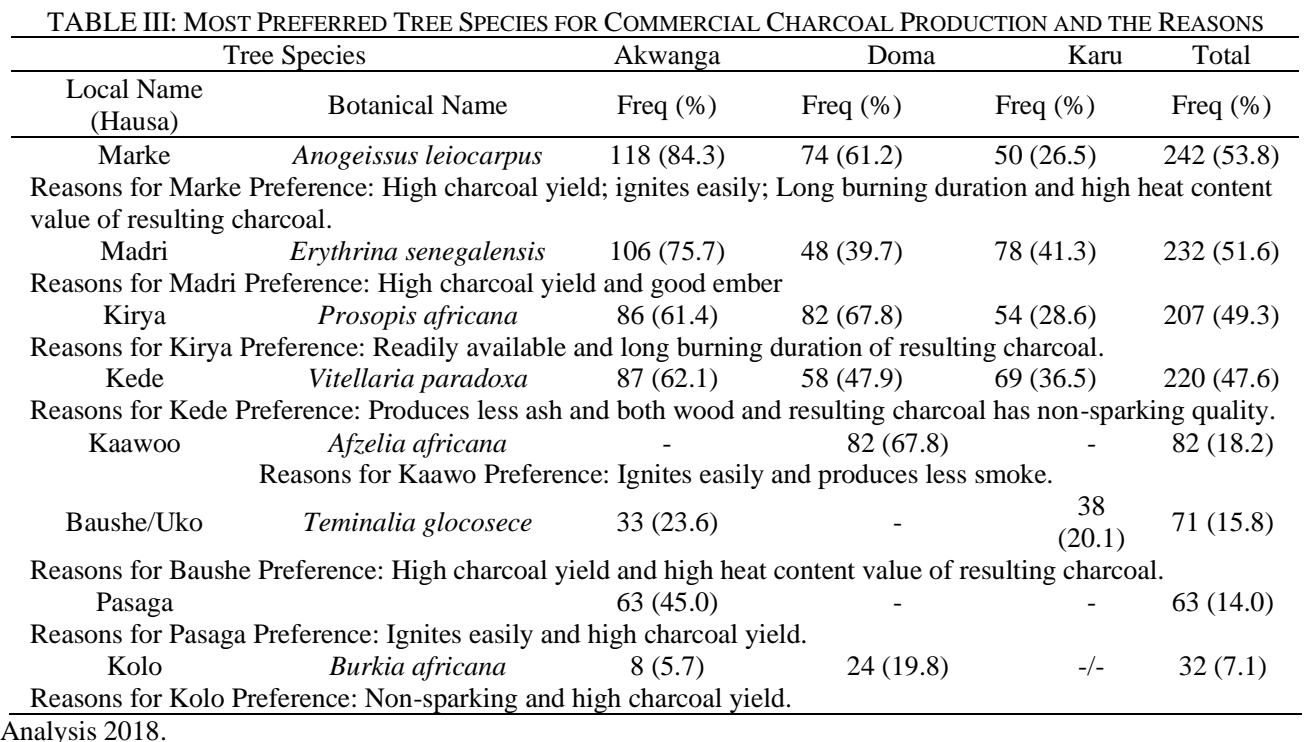

Source: Field Data Analysis 2018

\section{B. Preferences of Tree Species for Commercial Charcoal Production}

Table III presents the findings on tree species that were mostly preferred for commercial charcoal production by producers in Nasarawa State and reasons for their preference/choices.

Charcoal producers in the study area were found to have strong preference for some tree species in the production of commercial charcoal. Generally, Anogeissus leocarpus (Marke) was the most preferred tree species for charcoal production in Nasarawa State as indicated by $53.8 \%$ of the respondents. Erythrina senegalensis (Madri) which was preferred by $51.6 \%$ of the respondents ranked as the second most preferred specie, closely followed by Prosopis Africana (Kirya) and Vitellaria paradoxa which were accounted for by $49.3 \%$ and $47.6 \%$ of the sampled respondents. Other highly preferred tree species among commercial charcoal producers in Nasarawa State in descending order of preference included: Afzelia Africana (Kaawoo) (18.2\%), Teminalia glocosece (Baushe/Uko) (15.8\%), Pasaga tree (14\%) and Burkia Africana (Kolo) (7.1\%). Kituyi et al. [15] opined that charcoal producers' preference of tree species vary according to the region but are mainly indigenous species, hence, most of the tree species found to be among the preferred species in the study area are in concordance with those found in similar studies [11], [16] and [17] where similar species exists.

However, the study does not agree with the findings of Adeniji et al. [17] on the account that Prosopis Africana (Kirya) is the most preferred specie for commercial charcoal production. This could be because of differences in customers' preference as FGD revealed that although charcoal of Kiriya origin burns quite long and the wood are readily available, its demand is increasingly declining as 
customers are consistently complaining of its blistering (sparkling) nature. This justifies the statement by Chansa [18] that the reason for tree preference among charcoal producers is due to their particular species-specific characteristics rather than perhaps their abundance. Conversely, the finding on the most preferred specie corroborates that of Ogunsanwo et al. [19] who found that Anogeissus Leiocarpus (Marke) was the most preferred tree species in Oyo State and that of Charlotte [16]. Plate 2 presents bags of abandoned charcoal of Kirya origin at Saningye-Panda community.

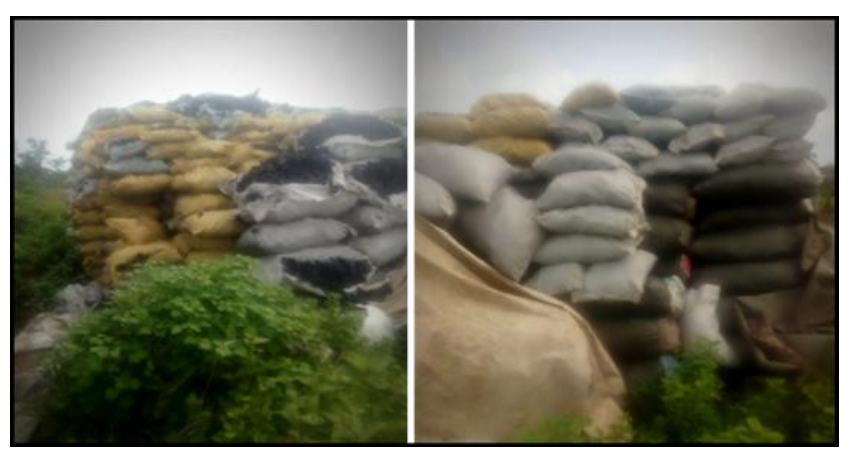

Plate 1. Abandoned/unsold Sacks of Charcoal of Kyria Origin due to Poor Demands at Saningye-Panda $\left(9^{\circ} 14^{\prime} 34.256^{\prime \prime} \mathrm{N} 7^{\circ} 50^{\prime} 19.883^{\prime \prime} \mathrm{E}\right)$. Source: Author's Photography (2018)

Variation was also observed in charcoal producers' preference of tree species across the three LGAs sampled for the study (Table III). Analysis of tree species preference in Akwanga LGA shows that $84.3 \%$ of the producers preferred Anogeissus Leiocarpus (Marke) thus making it the most preferred specie. The second most preferred specie was Erythrina senegalensis (Madri) in favour of which $75.7 \%$ indicated preference, followed by $62.1 \%$ who were in favour of Vitellaria paradoxa (Kede), $61.4 \%$ preferred Prosopis Africana (Kirya) tree, $45 \%$ preferred Pasaga, while Teminalia glocosece (Baushe/Uko) and Burkia Africana (Kolo) were preferred by $23.6 \%$ and $5.7 \%$ of the respondents respectively. The case in Doma LGA was totally different where Prosopis Africana (Kirya) and Afzelia Africana (Kaawoo) were rated as most preferred specie by $67.8 \%$ of the sampled respondents. The second most preferred species was Anogeissus Leiocarpus (Marke) as indicated by $61.2 \%$ respondents, followed by Vitellaria paradoxa (Kede) (47.9\%), Erythrina senegalensis (Madri) $(39.7 \%)$ and Burkia Africana (Kolo) (19.8\%). The preference of tree species in Karu showed that Erythrina senegalensis (Madri) was the most preferred specie as indicated by $41.3 \%$ of the respondents, Vitellaria paradoxa (Kede), Prosopis Africana (Kirya), Anogeissus Leiocarpus (Marke) and Teminalia glocosece (Baushe/Uko) ranked second, third, fourth and fifth as indicated by $36.5 \%, 28.6 \%, 26.5 \%$ and $20.1 \%$ of the respondents respectively.

These variations could be attributed to differences in the choices of their customer base/location and the use to which they put the supplied charcoal. Chansa [18] stated that "species which produce a lot of sparks are usually avoided particularly in the cold season when charcoal braziers are not only used for cooking but for heating and keeping homes warm. In the evening families would gather around a charcoal brazier before going to bed. At such moments, species which spark would cause damage to clothes and may also cause minor burns on the skin. The species selection based on these and other factors may continue for some time in the future for as long as sources of species are nearby".

\section{Reasons for Preferred Tree Species in Commercial Charcoal Production}

Table III further revealed that several reasons were given by the sampled respondents regarding their preference of tree species for commercial charcoal production. Among the reasons given by the $53.8 \%$ who preferred Anogeissus Leiocarpus (Marke) over other species were: high charcoal yield; easy ignition of the wood as well as longer burning duration and high heat content value of resulting charcoal. The $51.6 \%$ who preferred Erythrina senegalensis (Madri) opined that the specie has high charcoal yielding capacity and the resulting charcoal has good ember, which implies burning slowly without flames (good burning quality). Prosopis Africana (Kirya) was preferred by $49.3 \%$ because it's readily availability and longer burning duration of resulting charcoal and 47.6 preferred Vitellaria paradoxa (Kede) because it produces less ash and both the wood and resulting charcoal has non-sparking quality while $18.2 \%$ preferred Afzelia Africana (Kaawoo) because it generates less smoke and ignites easily. The preference of Teminalia glocosece (Baushe/Uko) by $15.8 \%$ of the sampled charcoal producers was ascribed to its high charcoal yield quality and high heat content value of resulting charcoal, $14 \%$ who were in favour of Pasaga tree ascribed their preference of the specie to its high charcoal yield and easy ignition capacity while the rest 7.1\% preferred Burkia Africana (Kolo) because it doesn't spark and it also has high charcoal yielding capacity. FGD revealed that the choice of non-sparking species of tree and those that generates less smoke is a function of the burning location as most producers who burn their charcoal around their homes claimed to have mostly gone for those.

According to a discussant in Agwashi community "usually, I prefer to use Kaawoo tree for my charcoal production when there is no specific request by a customer to use a particular tree species and this is because I burn my charcoal close to the house, hence Kaawoo is the best choice for me since it generates less smoke and its resulting charcoal burns easily and well".

Also, all the preferred tree species in Nasarawa State were in the hardwood category as mentioned during the FGD. According to Adeniji et al. [17], hardwood is most commonly used for charcoal production in Nigeria. The findings on the reasons for preference of tree species concur with Ogunsanwo et al. [19] who found that Anogeissus Leiocarpus was the most preferred of tree species in Oyo State due to having the highest calorific value. Kokou et al. [20] opined that the choice of resources for commercial charcoal production is not only related to the energy quality but also to the availability. Furthermore, Chansa [18] found that in Kapiri Mposhi Area of Central Zambia, the preferred species give good embers, hot fire, high heat content value, it last long in burning and burn easily while producing little smoke. 


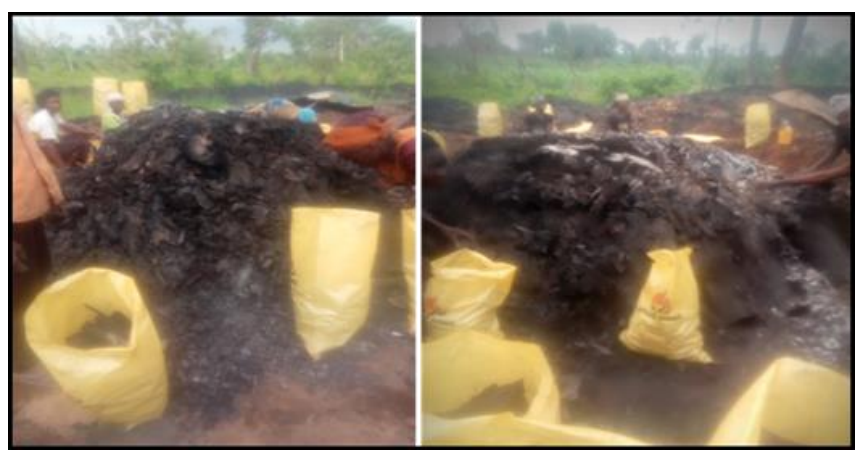

Plate 2. Charcoal Yield from Anogeissus Leiocarpus (Marke) Specie at a Saningye-Panda Production Site $\left(9^{\circ} 14^{\prime} 31.619^{\prime \prime} \mathrm{N} 7^{\circ} 50^{\prime} 15.594^{\prime \prime} \mathrm{E}\right)$.

\section{CONCLUSION}

Commercial charcoal production has over time become an indispensable means of livelihood among rural settlers in Nasarawa State. However, as observed during field activities, the production process has remained undeveloped with the traditional earth mound kiln being the only charcoal processing technology adopted by the producers. Though cost effective in comparison to other technologies, the traditional earth mound has been proven to be both inefficient and ineffective towards sustainable utilization of savanna woodland resources in the state.

A total of 22 tree species were identified as usable trees for charcoal production in the study area. Among these tree species, Teminalia glocosece (Baushe/uko), Andira inermis (Gwaska), Ficus Spp (Baure), Vitellaria paradoxa (Kede) and Gardinia aqualla (Gaude) were found to be the most commonly used species. Investigation into the producers' preference of tree species showed that eight (8) were mostly preferred out of which Anogeissus leiocarpus (Marke) (57.3\%), Erythrina senegalensis (Madri) (52.2\%) and Prosopis Africana (Kirya) (49.1\%) were among the top three. Marke, Kirya and Madri were the most preferred species in Akwanga, Doma and Karu production areas respectively. High charcoal yield, good combustion quality, high heat content of resulting charcoal, less ash production were the main reasons for their preferences.

Most of the preferred tree species have been depleted to the point that they are no longer commonly found for use among commercial charcoal producers in the state. Materials (basically trees) for charcoal production are now scarce and difficult to come by. The most endangered species due to commercial charcoal production were Anogeissus leiocarpus (Marke), Erythrina senegalensis (Madri) and Prosopis Africana (Kirya). However, pressure is currently on Teminalia glocosece (Baushe/Uko), Andira inermis (Gwaska), Ficus Spp (Baure), Vitellaria paradoxa (Kede) and Gardinia aqualla (Gaude) due to the difficulties in finding the endangered ones which constituted the most preferred species among producers in Nasarawa State. Hence, State energy policies should incorporate a law recognizing charcoal as a key source of energy in the State, thereby encouraging investments in the activity of commercial charcoal producers. Also, commercial charcoal producers in the production areas should be supported and encouraged by the State and Local government Authorities to practice reforestation of utilized tree species and also planting of woodlots in view of safeguarding indigenous tree species. Conservation plans and practical measures of replacing the extracted trees from the woodlands/forests for commercial charcoal production should form the basis for license issuance for charcoal production.

\section{REFERENCES}

[1] FAO, Assessing forest degradation: Towards the development of globally applicable guidelines. Forest Resources Assessment Working Paper 177. Food and Agriculture Organization of the United Nations, Rome. 2011.

[2] F. B. Dayo. (2012). "Opportunities for CDM Projects in Anglophone Sub-Saharan African Countries", Report of a Study Funded by AFTEG, World Bank.

[3] R.M. Martin, D. Kneeland, D.Brooks, R. Matta.(2012) (eds). FAO: 2012. State of World's Forests 2012. Food and Agriculture Organization of the United Nations, Rome.

[4] Global Forest Watch, World Resources Institute 2016, Accessed on (2018) www.globalforestwatch.org.

[5] Federal Government of Nigeria-FGN, Proposed National Biofuel Policy, Draft, Abuja: Nigerian Energy Commission. 2004.

[6] Resource Watch Agenda, Poverty Reduction through Civil Society Advocacy in Natural Resources and Environmental Governance in Ghana, 2010, Edition 4, 2-6.

[7] L.T. Ajibade. "Creating Environmental Awareness Techniques in Nigeria”. In Opoku-Agymang (eds) Culture, Science and Sustainable Development in Africa. The First University of Cape Coast and University of Ilorin Joint Conference 2009.

[8] UNFF, 12th session of the UN Forum on Forests (UNFF12) E/CN.18/SS/2017/2. May 1, 2017 to May 5, 2017. New York, United States. https://documents-dds ny.un.org/doc/UNDOC/GEN/N17/034/53/PDF/N1703453.pdf?OpenE lement.

[9] Kenya Forest Service-KFS, Analysis of the Charcoal Value Chain in Kenya. August 26, 2013. Retrieved from: http://www.kenyaforestservice.org/document s/redd/Charcoal\%20Value\%20Chain\%20An alysis.pdfAccessed 09/09/2015.

[10] G. C. Monela, A. Okting'ati and P. M. Kiwele (1993). "SocialEconomic Aspects of Charcoal Consumption and Environmental Consequences Along Dar es Salaam-Morogoro Highway, Tanzania”. Journal of Forest Ecology and Management 58: 249-258.

[11] D. O. Beatrice, N. Isaac, O. Elizabeth, W. O. Francis and M. Emmanuel (2014). "The Charcoal Industry in Ghana: An Alternative Livelihood Option for Displaced Illegal Chainsaw Lumber Producers". Tropenbos International, Wegeningen, the Netherlands, $132 \mathrm{pp}$.

[12] National Population Commission (NPC) [Nigeria], Final Results of 2006 Census. Official Gazette of 2nd February, 2009. Abuja, Nigeria.

[13] R. V. Krejcie, \& D. W. Morgan, "Determining sample size for research activities". Educational and Psychological Measurement 1970, 30, 607-610.

[14] M. B. Miles and A. M. Huberman (1994). "Qualitative data analysis": An expanded sourcebook (2nd ed.). Sage Publications, Inc.

[15] E. Kituyi, L. Marufa, B. Huber, S. Wandiga, I. Jumba, M. Andreae and G. Helas. "Bio-fuels Consumption Rates in Kenya". Biomass and Bioenergy 2001, 20:83-99.

[16] L. H. Charlotte, "Burning Nigerian forests on European barbecues: A carbon footprint and cost comparison between imported Nigerian charcoal and sustainably produced charcoal in the European Union". Published MSc Thesis Energy Science Utrecht University; Faculty of Geoscience; 30 ECTS. Date: 4th June 2018.

[17] O. A. Adeniji, O. S. Zaccheaus, B. S. Ojo and A. S. Adedeji (2015). "Charcoal Production and Producers' Tree Species Preference in Borgu Local Government Area of Niger State, Nigeria". Journal of Energy Technologies and Policy, www.iiste.org ISSN 2224-3232 (Paper) ISSN 2225-0573 (Online) Vol.5, No.11, 2015.

[18] W. Chansa (2000). "Utilization of woody plant species by local communities in Mumbwa Game Management Areas, Zambia". Unpublished MSc. Thesis, University of Zimbabwe, Harare, pp 1-99.

[19] O. Y. Ogunsanwo, A. A. Aiyeloja and C. Uzo (2007). "Production Technique and the Influence of Wood Species on the Properties of Charcoal in Nigeria, A Case Study of Oyo State". Agricultural Journal, 2: 131-133.

[20] K. Kokou, Y. Nuto and H. Atsri (2009). "Impact of Charcoal Production on Woody Plant Species in West Africa: A Case Study in Togo". Scientific Research and Essay, Vol.4 (9), pp. 881-893, September, 2009 Available online at http://www.academicjournals.org/SRE ISSN 1992-2248 C 2009 Academic Journals. 